\title{
STUDI KEADAAN OKSIDASI BESI PADA AIR HUJAN
}

\author{
HIDAYAH $^{1}$, DEDE SUHENDAR $^{1 *}$, TETY SUdARTI ${ }^{1}$, DAN EMAY MAESAROH ${ }^{1}$ \\ ${ }^{1}$ Jurusan Kimia, Fakultas Sains dan Teknologi, UIN Sunan Gunung Djati Bandung, \\ Jl. A. H. Nasution No.105 Cibiru Kota Bandung \\ *alamat email korespondensi: dede.suhendar@uinsgd.ac.id
}

\begin{abstract}
Informasi Artikel Abstrak/Abstract
Riwayat Naskah :

Diterima pada 22

Mei 2019

Air hujan merupakan sumber air permukaan dan air tanah. Air hujan terbentuk melalui

Diterima setelah

direvisi pada 3 Juli

2019

Diterbitkan pada 5

Juli 2019 beberapa proses yakni kondensasi, presipitasi, evaporasi, dan transpirasi. Air hujan memiliki kandungan besi dalam bentuk partikulat dan terlarutnya seperti ferro $\left(\mathrm{Fe}^{2+}\right)$ dan ferri $\left(\mathrm{Fe}^{3+}\right)$. Tujuan dari penelitian ini yaitu untuk menentukan kandungan $\mathrm{Fe}$ total, $\mathrm{Fe}(\mathrm{II})$ dan $\mathrm{Fe}(\mathrm{III})$ dalam air hujan serta perbandingannya dengan air hujan dari tiga tempat yang berbeda dan untuk mempelajari kandungan air hujan yang dapat mereduksi Fe(III). Fe total dianalisis dengan menggunakan instrumen Spektrofotometer Serapan Atom (SSA). Ion Fe(II) dan $\mathrm{Fe}(\mathrm{III})$ dianalisis dengan instrumen Spektrofotometer UV-Vis menggunakan ligan Fenantrolin dan KSCN sehingga membentuk senyawa kompleks $\left[\mathrm{Fe}\left(\mathrm{C}_{12} \mathrm{H}_{8} \mathrm{~N}_{2}\right)_{3}\right]^{2+}$ dan $\left[\mathrm{Fe}(\mathrm{SCN})_{6}\right]^{3-}$. Derajat keasaman air hujan dianalisis menggunakan $\mathrm{pH}$ meter sedangkan keadaan oksidasi besi pada air hujan dianalisis menggunakan Spektrofotometer UV-Vis dengan pelarutan aqua $\mathrm{dm}$ dan air hujan yang turun di kawasan industri, pegunungan dan pemukiman. Hasil analisis menunjukkan kandungan Fe total, Fe(II) serta Fe(III) dalam air hujan yang turun sekitar

Kata Kunci: air hujan; besi ;

kompleks;

Spektrofotometer

UV-Vis; SSA. industri, pegunungan dan pemukiman secara berturut-turut yaitu Fe total 0,$5655 ; 1,6854$; dan 2,4232 mg/L, Fe(II) 0,0867; 0,2232 dan 0,0731 mg/L, dan Fe(III) 0,5198; 0,4994 dan 0,5672 $\mathrm{mg} / \mathrm{L}$. Dari perbandingan geseran panjang gelombang maksimum sinar tampak larutan $\mathrm{FeSO}_{4} .7 \mathrm{H}_{2} \mathrm{O}$ teknis dan pro analisis dengan pengompleks fenantrolin diperoleh bahwa air hujan memiliki daya reduksi terhadap ion $\mathrm{Fe}^{3+}$.
\end{abstract}

Keywords: rainwater; iron ; complex; UV-Vis Spectrophotometer; $A A S$.

\begin{abstract}
Rainwater is a source of surface water and ground water. Rainwater is formed through several processes namely condensation, precipitation, evaporation and transpiration. Rainwater has an iron content in the form of particulates and dissolves such as ferro $\left(\mathrm{Fe}^{2+}\right)$ and ferric $\left(\mathrm{Fe}^{3+}\right)$. The purpose of this study is to determine the content of total $\mathrm{Fe}, \mathrm{Fe}(\mathrm{II})$ and $\mathrm{Fe}(\mathrm{III})$ in rainwater and its comparison with rainwater from three different places and to study the content of rainwater that can reduce Fe(III). Total Fe was analyzed using Atomic Absorption Spectrophotometer (AAS) instrument. $\mathrm{Fe}(\mathrm{II})$ and $\mathrm{Fe}(\mathrm{III})$ ions were analyzed with an UV-Vis spectrophotometer using Fenantrolin and KSCN ligands to form complex compounds $\left[\mathrm{Fe}\left(\mathrm{C}_{12} \mathrm{H}_{8} \mathrm{~N}_{2}\right)_{3}\right]^{2+}$ and $\left[\mathrm{Fe}(\mathrm{SCN})_{6}\right]^{3-}$. The degree of acidity of rainwater was analyzed using a pH meter while the oxidation state of iron in rainwater was analyzed using a $U V$-Vis spectrophotometer by dissolving aqua dm and falling rainwater in industrial estates, mountains and settlements. The results of the analysis show the content of total $\mathrm{Fe}, \mathrm{Fe}(\mathrm{II})$ and $\mathrm{Fe}(I I I)$ in rainwater that falls around the industry, mountains and settlements respectively, namely Fe total 0.5655; 1.6854; and $2.4232 \mathrm{mg} / \mathrm{L}, \mathrm{Fe}(\mathrm{II}) 0.0867 ; 0.2232$ and $0.0731 \mathrm{mg} / \mathrm{L}$, and $\mathrm{Fe}(\mathrm{III})$ 0.5198; 0.4994 and $0.5672 \mathrm{mg} / \mathrm{L}$. From the comparison of the maximum wavelength shear of the visible light the technical and pro $\mathrm{FeSO}_{4} \cdot 7 \mathrm{H}_{2} \mathrm{O}$ solution with phenanthroline complexing was obtained that the rain water had a reduction in the $\mathrm{Fe}^{3+}$ ion.
\end{abstract}

\section{PENDAHULUAN}

Indonesia merupakan negara tropis sehingga mempunyai curah hujan yang tinggi dan dapat terjadi sepanjang tahun. Hal ini disebabkan karena Indonesia mempunyai tingkat keragaman yang tinggi baik secara temporal (waktu) maupun secara keruangan (tempat). Keadaan ini disebabkan oleh posisi Indonesia yang dilewati oleh garis katulistiwa dan keberadaannya di antara dua benua (Benua Asia dan Benua Australia) dan dua samudera (Samudera Pasifik dan Samudera
Hindia) yang mempengaruhi pergerakan angin serta menimbulkan curah hujan [1].

Air hujan merupakan sumber air permukaan dan air tanah. Air hujan terbentuk melalui beberapa proses yakni kondensasi, presipitasi, evaporasi, dan transpirasi. Air dari daratan serta air laut dapat mengalami proses penguapan sehingga membentuk uap air. Seluruh uap air yang terbentuk akan terbawa angin menuju atmosfer selanjutnya akan jatuh ke laut dan daratan sebagai air hujan [2]. Sebagian air hujan yang turun ke permukaan akan diserap oleh 
tanaman, mengalir ke permukaan tanah dan dapat meresap dalam tanah lalu masuk ke sungai sehingga mengalir menuju laut. Sebagian air hujan dapat menguap dan terangkat kembali menuju atmosfer [3].

Air hujan memiliki peran yang sangat penting bagi makhluk hidup salah satunya tumbuhan. Dalam tumbuhan air hujan berperan sebagai nutrisi untuk pertumbuhan tumbuhan yaitu ditandai dengan tingginya tumbuhan tersebut [4]. Dalam air hujan memiliki kandungan besi yang terdapat dalam bentuk kation ferro $\left(\mathrm{Fe}^{2+}\right)$ dan ferri $\left(\mathrm{Fe}^{3+}\right)$ [5]. Kandungan besi dalam air hujan berperan sebagai nutrisi fitoplankton [6]. Selain itu, kandungan besi pada air hujan merupakan nutrisi penting untuk tanaman. Besi dapat diserap oleh tanaman dan ditransportasi ke dalam akar sebagai besi(II) [7].

Berdasarkan penelitian dari Kieber dkk pada tahun 2015, konsentrasi $\mathrm{Fe}$ (II) dan $\mathrm{Fe}$ (III) dalam air hujan masing-masing diperoleh sebesar 3,8 nM dan12 nM [6]. Selain mengandung besi, air hujan juga memiliki kandungan hidrogen peroksida $\left(\mathrm{H}_{2} \mathrm{O}_{2}\right)$. Konsentrasi hidrogen peroksida dalam air hujan yaitu $15 \mu \mathrm{M}$ [8] dan berada antara 20 sampai $30 \mu \mathrm{M}$ [9]. Hidrogen peroksida dapat bertindak sebagai oksidator maupun reduktor dalam atmosfer [9].

\section{EKSPERIMEN}

\section{Material}

Bahan-bahan yang digunakan dalam penelitian ini adalah air bebas mineral (akua DM), larutan induk $\mathrm{Fe}$ (II) $1000 \mathrm{mg} / \mathrm{L}$, larutan induk $\mathrm{Fe}$ (III) $1000 \mathrm{mg} / \mathrm{L}, \mathrm{FeCl}_{3}$ (pa merck), $\mathrm{FeSO}_{4} .7 \mathrm{H}_{2} \mathrm{O}$ (p.a dan teknis), Larutan 1,10 Fenantrolin, Buffer asetat $\mathrm{pH} 4,5, \mathrm{CH}_{3} \mathrm{COONa}, \mathrm{CH}_{3} \mathrm{COOH}, \mathrm{HNO}_{3} 65$ $\%$, larutan induk Fe $1000 \mathrm{mg} / \mathrm{L}, \mathrm{KSCN} 2 \mathrm{M}, \mathrm{HCl}$ 4M dan sampel air hujan.

\section{Instrumentasi}

Instrumentasi yang digunakan dalam penelitian ini yaitu: $\mathrm{pH}$ meter, spektrofotometer UV-Vis merek Agilent Technologies tipe carry 60 dan Spektrofotometer Serapan Atom (SSA) merek Agilent Technologies tipe 200 Series.

\section{Prosedur}

\section{Preparasi sampel}

Teknik penampungan air hujan dilakukan dengan menampung air hujan yang jatuh dari langit tanpa adanya perantara, dengan menggunakan wadah berbahan polipropilen. Hasil penampungan air hujan kemudian dipindahkan ke dalam botol yang telah bersih, dibilas dengan aqua $\mathrm{dm}$ dan dibilas dengan air hujan sebanyak tiga kali. Botol ditutup hingga rapat, kemudian air hujan diawetkan secara fisika, yaitu dengan didinginkan dalam lemari es pada suhu $4^{\circ} \mathrm{C}$. Sampel tersebut dicampurkan dengan volume yang sama yaitu $50 \mathrm{~mL}$ setiap kali hujan.

Penampungan sampel air hujan dilakukan di tiga kawasan yaitu di sekitar industri, pegunungan dan pemukiman. Adapun titik koordinat masingmasing penampungan sampel air hujan yaitu sebagai berikut:

- Kawasan industri (kampung Cipacing, Desa Mekar Bakti, Kecamatan Pamulihan, Kabupaten Sumedang) di sekitar titik koordinasi (-6.9234 $\left.{ }^{\circ} \mathrm{LU}, 107.8318^{\circ} \mathrm{BT}\right)$

- Kawasan pegunungan (kampung Mekarsari, Desa Mekarsari, Kecamatan Cimaung, Kabupaten Bandung) di sekitar titik koordinasi $\left(-7.1080^{\circ} \mathrm{LU}, 107.5698^{\circ} \mathrm{BT}\right)$

- Kawasan pemukiman (kampung Haurngombong, Desa Haurngombong, Kecamatan Pamulihan, Kabupaten Sumedang) di sekitar titik koordinasi (-6.9127 ${ }^{\circ} \mathrm{LU}$, $107.8361{ }^{\circ} \mathrm{BT}$ )

\section{Pembuatan Larutan Baku Fe total 10 mg/L}

Sebanyak $1 \mathrm{~mL}$ larutan baku standar besi $1000 \mathrm{mg} / \mathrm{L}$ dipipet dalam labu ukur $10 \mathrm{~mL}$. Setelah itu, ditambahkan larutan pengencer ( $\mathrm{HNO}_{3}$ 0,05 $\mathrm{M}$ diencerkan dengan akua DM dalam labu ukur $100 \mathrm{~mL}$ ) sampai tanda batas untuk memperoleh larutan baku besi $100 \mathrm{mg} / \mathrm{L}$. Sebanyak 2,5 mL larutan baku besi $100 \mathrm{mg} / \mathrm{L}$ dipipet ke dalam labu ukur $25 \mathrm{~mL}$ di tanda bataskan dengan larutan pengencer, sehingga diperoleh larutan baku besi $10 \mathrm{mg} / \mathrm{L}$.

\section{Pembuatan Larutan Deret Standar Fe total}

Pembuatan larutan deret standar Fe total dibuat dari larutan baku besi $10 \mathrm{mg} / \mathrm{L}$ dengan rentang konsentrasi 0,$5 ; 1,0 ; 1,5 ; 2 ;$ dan $2,5 \mathrm{mg} / \mathrm{L}$ dalam labu ukur $10 \mathrm{~mL}$. Larutan deret standar kemudian diukur menggunakan SSA pada panjang gelombang 248,3 $\mathrm{nm}$. Hasil pengukuran diperoleh kurva kalibrasi antara variasi konsentrasi dengan absorbansi. Dimana $\mathrm{R}^{2} \leq 0,995$ dilakukan pengukuran ulang sampai memperoleh nilai $R^{2} \geq$ 0,995 .

\section{Pengukuran Fe total dalam Sampel Air Hujan}

Sebanyak $50 \mathrm{~mL}$ masing-masing sampel air hujan (industri, pegunungan dan pemukiman) 
yang telah dikocok dimasukan dalam gelas kimia $100 \mathrm{~mL}$. Kemudian ditambahkan $5 \mathrm{~mL} \mathrm{HNO}_{3}$ pekat dipanaskan perlahan-lahan sampai volumenya $15-20 \mathrm{~mL}$. Setelah itu, diencerkan dengan akua DM dalam labu ukur $50 \mathrm{~mL}$ dan dianalisis menggunakan instrumen SSA.

\section{Pembuatan Larutan Baku Fe(II) 10 mg/L}

Sebanyak 0,4979 $\mathrm{g} \quad \mathrm{FeSO}_{4}$ ditimbang dengan teliti menggunakan neraca analitik. Selanjutnya dilarutkan dengan sedikit akua DM, dipindahkan dalam labu ukur $100 \mathrm{~mL}$. Setelah itu, larutan tersebut diencerkan dengan akua DM sampai tanda batas, sehingga diperoleh larutan baku $\mathrm{Fe}(\mathrm{II}) 1000 \mathrm{mg} / \mathrm{L}$. Kemudian dilakukan pengenceran untuk memperoleh konsentrasi larutan baku $100 \mathrm{mg} / \mathrm{L}$ dengan memipet larutan $1000 \mathrm{mg} / \mathrm{L}$ sebanyak $10 \mathrm{~mL}$ pada labu $100 \mathrm{~mL}$. Sedangkan untuk memperoleh konsentrasi larutan baku $10 \mathrm{mg} / \mathrm{L}$ yaitu dengan memipet larutan 100 $\mathrm{mg} / \mathrm{L}$ sebanyak $5 \mathrm{~mL}$ dalam labu $50 \mathrm{~mL}$.

\section{Pembuatan Deret Standar Fe(II)}

Larutan deret standar $\mathrm{Fe}(\mathrm{II})$ yaitu dengan membuat rentang konsentrasi 0,$2 ; 0,4 ; 0,6 ; 0,8$; $1,0 \mathrm{mg} / \mathrm{L}$ dari larutan baku $10 \mathrm{mg} / \mathrm{L}$ dalam labu ukur $10 \mathrm{~mL}$. Masing-masing larutan deret standar ditambahkan 1,5 mL 1,10 fenantrolin dan 1,5 mL buffer asetat $\mathrm{pH}$ 4,5. Kemudian diencerkan dengan aqua $\mathrm{dm}$ sampai tanda batas dan didiamkan selama 15 menit. Selanjutnya masingmasing larutan deret standar diukur menggunakan Spektrofotometer UV-Vis pada panjang gelombang $509 \mathrm{~nm}$. Hasil pengukuran diperoleh kurva kalibrasi dimana $\mathrm{R}^{2} \leq 0,995$ dilakukan pengukuran ulang sampai memperoleh nilai $R^{2} \geq$ 0,995 .

\section{Pengukuran Fe(II) dalam Sampel Air Hujan}

Sebanyak $2 \mathrm{~mL}$ sampel air hujan yang turun sekitar industri, pegunungan dan pemukiman dipipet kemudian dimasukan ke dalam labu ukur $10 \mathrm{~mL}$. Selanjutnya masing-masing sampel air hujan berdasarkan lokasi penampungan air hujan ditambahkan 1,5 mL 1,10 fenantrolin, 1,5 mL buffer asetat $\mathrm{pH} 4,5$ dan diencerkan dengan aqua dm sampai tanda batas. Setelah itu didiamkan selama 15 menit dan dianalisis menggunakan instrumen Spektrofotometer UV-Vis pada panjang gelombang $509 \mathrm{~nm}$.

\section{Pembuatan Larutan Baku Fe(III) $10 \mathrm{mg} / \mathrm{L}$}

Sebanyak 0,0290 $\mathrm{g} \mathrm{FeCl}_{3}$ ditimbang dengan teliti menggunakan neraca analitik. Selanjutnya dilarutkan dengan akua DM, dipindahkan dalam labu ukur $100 \mathrm{~mL}$ diencerkan dengan akua DM sampai tanda batas, sehingga diperoleh larutan baku $\mathrm{Fe}(\mathrm{III}) 100 \mathrm{mg} / \mathrm{L}$. Kemudian dilakukan pengenceran untuk memperoleh konsentrasi larutan baku $10 \mathrm{mg} / \mathrm{L}$ dengan mengambil $5 \mathrm{~mL}$ dari larutan baku Fe(III) $100 \mathrm{mg} / \mathrm{L}$ dalam labu ukur $50 \mathrm{~mL}$.

\section{Pembuatan Deret Larutan Standar Fe(III)}

Deret larutan standar Fe(III) yaitu dengan membuat konsentrasi 0,$2 ; 0,4 ; 0,6 ; 0,8 ; 1,0 \mathrm{mg} / \mathrm{L}$ dari larutan baku $10 \mathrm{mg} / \mathrm{L}$ dalam labu ukur $25 \mathrm{~mL}$. Masing-masing larutan deret standar ditambahkan $2 \mathrm{~mL} \mathrm{HCl} 4 \mathrm{M}$ dan $5 \mathrm{~mL}$ KSCN $2 \mathrm{M}$. Kemudian diencerkan dengan akua DM sampai tanda batas , didiamkan selama 15 menit dan dianalisis menggunakan Spektrofotometer UV-Vis pada panjang gelombang $483 \mathrm{~nm}$. Hasil pengukuran diperoleh kurva kalibrasi dimana $\mathrm{R}^{2} \leq 0,995$ dilakukan pengukuran ulang sampai memperoleh nilai $R^{2} \geq 0,995$.

\section{Pengukuran Fe(III) pada Sampel Air Hujan}

Sebanyak $25 \mathrm{~mL}$ masing-masing sampel air hujan (industri, pegunungan dan pemukiman) yang telah dikocok dimasukan dalam gelas kimia $100 \mathrm{~mL}$. Dipanaskan perlahan-lahan sampai volumenya 10-15 mL kemudian dimasukan dalam labu ukur $25 \mathrm{~mL}$. Corong yang telah digunakan dibilas dan dimasukan air bilasannya ke dalam labu ukur $25 \mathrm{~mL}$. Setelah itu, ditambahkan $2 \mathrm{~mL}$ $\mathrm{HCl} 4 \mathrm{M}, 5 \mathrm{~mL}$ KSCN $2 \mathrm{M}$ diencerkan dengan aqua $\mathrm{dm}$ dan ditanda bataskan. Kemudian didiamkan selama 15 menit. Selanjutnya diukur kandungan Fe(III) dalam masing-masing sampel air hujan berbagai lokasi menggunakan instrumen SSA pada panjang gelombang $483 \mathrm{~nm}$.

\section{Pemindaian Panjang Gelombang Absorpsi Fe(II)}

Sebanyak 0,0498 g serbuk $\mathrm{FeSO}_{4} .7 \mathrm{H}_{2} \mathrm{O}$ ditimbang secara teliti menggunakan neraca analitik. Selanjutnya dilarutkan dengan masingmasing sampel air hujan (industri, pegunungan dan pemukiman) dan aqua $\mathrm{dm}$. Kemudian dimasukan ke dalam labu ukur $100 \mathrm{~mL}$, ditambahkan 1,5 $\mathrm{mL}$ fenantrolin dan ditanda bataskan sehingga diperoleh larutan $100 \mathrm{mg} / \mathrm{L}$. Selanjutnya dilakukan pemindaian menggunakan Spektrofotometer UV-Vis pada panjang gelombang 400-800 $\mathrm{nm}$ sehingga menghasilkan kurva antara panjang gelombang dan absorbansi. 


\section{HASIL DAN PEMBAHASAN}

\section{Pengukuran Fe Total dalam Air Hujan}

Analisis logam Fe total dalam air hujan menggunakan metode Spektrofotometer Serapan Atom (SSA). Penentuan kandungan logam Fe dalam sampel air hujan dilakukan pada panjang gelombang 248,3 $\mathrm{nm}$. Panjang gelombang ini merupakan panjang gelombang optimum untuk logam $\mathrm{Fe}$ dengan metode Spektrofotometer Serapan Atom (SSA). Metode ini merupakan metode yang menggunakan mekanisme atomisasi dengan proses pengubahan sampel dalam bentuk larutan menjadi spesies atom dalam nyala. Larutan sampel diubah menjadi uap atom sehingga nyala mengandung atom unsur-unsur yang dianalisis. Beberapa atom akan tereksitasi secara termal oleh nyala, tetapi kebanyakan atom akan tetap tinggal sebagai atom netral dalam keadaan dasar.

Pada analisis kandungan $\mathrm{Fe}$ total dalam sampel air hujan, digunakan larutan $\mathrm{HNO}_{3}$ pekat yang bertindak sebagai asam pengoksidasi kuat sehingga sampel air hujan akan teroksidasi sempurna dengan meninggalkan elemen-elemen pada larutan asam dalam bentuk senyawa anorganik yang sesuai untuk dianalisis. Tabel.1 merupakan hasil pengukuran kandungan Fe total dalam air hujan di berbagai lokasi yaitu sebagai berkut:

Tabel 1. Hasil Pengukuran Fe total dalam air hujan

\begin{tabular}{cc}
\hline Lokasi & $\begin{array}{c}\text { Kandungan Fe total } \\
(\mathrm{mg} / \mathrm{L})\end{array}$ \\
Sampling & 0,5655 \\
Industri & 1,6854 \\
Pegunungan & 2,4232 \\
Pemukiman & \\
\hline
\end{tabular}

Hasil pengukuran kandungan $\mathrm{Fe}$ total dalam sampel air hujan yaitu pada rentang antara $0,5655-$ $2,4232 \mathrm{mg} / \mathrm{L}$. Perbedaan kandungan $\mathrm{Fe}$ total dalam air hujan dikarenakan berbedanya lokasi penampungan air hujan sehingga dapat mempengaruhi hasil kandungan $\mathrm{Fe}$ totalnya. Kandungan Fe total terdiri dari kandungan $\mathrm{Fe}$ (II) dan $\mathrm{Fe}(\mathrm{III})$.

Kandungan Fe total tertinggi yaitu di sekitar penampungan air hujan yang turun sekitar pemukiman. Hal ini dapat dilihat dari hasil pengukuran kandungan $\mathrm{Fe}$ (III) dan $\mathrm{Fe}$ (II) yang menunjukkan bahwa kandungan $\mathrm{Fe}(\mathrm{III})$ lebih tinggi dibandingkan kandungan $\mathrm{Fe}(\mathrm{II})$ dalam air hujan. Begitu pun untuk kandungan Fe total hasil penampungan air hujan yang turun sekitar pegunungan dan industri yang dipengaruhi oleh tingginya kandungan $\mathrm{Fe}(\mathrm{III})$ dibandingkan kandungan $\mathrm{Fe}(\mathrm{II})$. Sehingga $\mathrm{Fe}$ total yang dihasilkan dalam air hujan sebagian besar adalah sebagai $\mathrm{Fe}(\mathrm{III})$ karena Fe(III) keberadaannya lebih stabil dibandingkan Fe(II). Perbedaan tingginya kandungan $\mathrm{Fe}$ total di setiap kawasan dipengaruhi oleh partikulat yang terdapat di masing-masing kawasan tidak bertahan lama di atmosfer sehingga turun kembali ke permukaan melalui air hujan. Kandungan $\mathrm{Fe}$ total terendah berada di kawasan industri karena partikulat yang dihasilkan di kawasan ini akan berefek ke kawasan yang jaraknya jauh dari kawasan industri.

\section{Pengukuran Fe(II) dalam Air Hujan}

Pengukuran Fe(II) dalam sampel air hujan bertujuan untuk mengetahui kandungan $\mathrm{Fe}(\mathrm{II})$ dalam air hujan di beberapa lokasi penampungan air hujan diantaranya sekitar industri, pegunungan dan pemukiman. Lokasi penampungan sampel air hujan diambil dari berbeda lokasi, hal ini dilakukan untuk mengetahui perbedaan kandungan $\mathrm{Fe}$ (II) antar lokasi tersebut. Penentuan kadar Fe(II) menggunakan Spektrofotometer UVVis dapat dilakukan dengan mereaksikan sampel dengan agen pengkompleks sehingga akan menghasilkan warna yang spesifik sesuai dengan pengkompleks yang digunakan.

Pengkompleks yang digunakan adalah ligan fenantrolin. Fenantrolin menyumbangkan dua atom donor dalam pembentukan ikatan kovalen koordinat. Ketika Fe(II) direaksikan dengan ligan fenantrolin dapat membentuk senyawa kompleks yang menghasilkan warna merah jingga dengan menyerap daerah sinar tampak pada panjang gelombang $509 \mathrm{~nm}$. Reaksi yang terjadi yaitu:

$$
\begin{array}{ccc}
\mathrm{Fe}^{2+}{ }_{(\mathrm{aq})}+ & 3 \mathrm{C}_{12} \mathrm{H}_{8} \mathrm{~N}_{2 \text { (aq) }} \leftrightarrow\left[\mathrm{Fe}\left(\mathrm{C}_{12} \mathrm{H}_{8} \mathrm{~N}_{2}\right)_{3}\right]^{2+}{ }_{\text {(aq) }} \\
\text { (Hijau } & \text { (Tak } & \text { (Merah jingga) } \\
\text { muda) } & \text { berwarna) }
\end{array}
$$

Kandungan $\mathrm{Fe}(\mathrm{II})$ dalam air hujan di sekitar industri, pegunungan dan pemukiman dapat dilihat pada Tabel 2.

Tabel 2. Hasil Pengukuran Fe(II) dalam Sampel Air Hujan

\begin{tabular}{ccc}
\hline Lokasi & $\begin{array}{c}\text { Kandungan Fe(II) } \\
(\mathrm{mg} / \mathrm{L})\end{array}$ & $\begin{array}{c}\text { Fe(II) } \\
(\%)\end{array}$ \\
\hline Sampling & 0,0867 & 14,29 \\
Industri & 0,2232 & 30,89 \\
Pegunungan & 0,0731 & 11,42 \\
Pemukiman & & \\
\hline
\end{tabular}

Kandungan $\mathrm{Fe}(\mathrm{II})$ dalam air hujan daerah pegunungaan lebih tinggi dibandingkan di daerah hasil penampungan air hujan sekitar industri dan pemukiman. Hal ini terjadi karena daerah 
pegunungan mayoritas tumbuhan yang hidup cenderung lebih tumbuh dengan baik dibandingkan dengan pemukiman dan industri. Salah satu penyebabnya yaitu adanya besi. Besi merupakan mikronutrien penting untuk hampir semua organisme hidup. Karena besi memainkan peran penting dalam proses metabolisme seperti sintesis DNA, respirasi dan fotosintesis. Meskipun besi terdapat dalam bentuk besi(II) dan besi(III) tetapi hanya diambil atau diserap oleh tumbuhan dalam bentuk besi(II). Dalam tumbuhan besi(II) berfungsi untuk penyerapan atau transportasi ke dalam akar [7]. Selain itu, besi(II) memiliki pengaruh pada kesuburan tanah untuk tumbuhan. Berdasarkan penelitian dari Alaa Idris Badawy Abou-Sreea dkk pada tahun 2017 bahwa kombinasi antara $\mathrm{FeSO}_{4}$ dan kalium humat merupakan pupuk yang sempurna untuk pertumbuhan. Kombinasi ini dapat mempengaruhi terhadap pertumbuhan tanaman seperti tinggi tanaman, jumlah cabang, biji dan yang lainnya [10].

Kandungan $\mathrm{Fe}(\mathrm{II})$ tertinggi kedua yaitu hasil penampungan air hujan di sekitar industri, hal ini disebabkan karena adanya pengaruh dari aktivitas industri sehingga menyebabkan tingginya kandungan $\mathrm{Fe}(\mathrm{II})$ dalam air hujan. Tumbuhan yang tumbuh di sekitar industri dapat tumbuh namun tidak tumbuh seperti tumbuhan yang tumbuh di sekitar pegunungan dan pemukiman. Berdasarkan hasil yang diperoleh bahwa kandungan $\mathrm{Fe}(\mathrm{II})$ dalam air hujan menghasilkan kandungan yang lebih rendah dibandingkan kandungan $\mathrm{Fe}$ (III) dalam air hujan. Hal ini terjadi karena $\mathrm{Fe}(\mathrm{II})$ keadaannya lebih tidak stabil dibandingkan Fe(III) sehingga Fe(II) lebih mudah teroksidasi menjadi Fe(III).

\section{Pengukuran Fe(III) dalam Air Hujan}

\begin{abstract}
Pengukuran kandungan $\mathrm{Fe}(\mathrm{III})$ dalam air hujan menggunakan metode analisa spektrofotometer UV-Vis dimana metode ini dilakukan dengan mengkomplekskan zat yang akan dianalisa dengan pengkompleks besi yang akan membentuk suatu warna yang spesifik. $\mathrm{Fe}(\mathrm{III})$ direaksikan dengan ligan $\mathrm{SCN}^{-}$akan membentuk senyawa kompleks $\left[\mathrm{Fe}(\mathrm{SCN})_{6}\right]^{3-}$. Senyawa kompleks ini dapat menyerap daerah sinar tampak pada panjang gelombang $483 \mathrm{~nm}$. Reaksi yang terjadi yaitu:
\end{abstract}

$$
\begin{aligned}
& \mathrm{Fe}^{3+}{ }_{(\mathrm{aq})}+6 \mathrm{SCN}_{(\mathrm{aq})}^{-} \leftrightarrow\left[\mathrm{Fe}(\mathrm{SCN})_{6}\right]_{(\mathrm{aq})}^{3-} \\
& \text { (Kuning (Tak (Merah Tua) } \\
& \text { kecoklatan) berwarna) }
\end{aligned}
$$

Dalam reaksi pengkompleksan antara $\mathrm{Fe}(\mathrm{III})$ dengan ligan $\mathrm{SCN}^{-}$ditambahkan larutan $\mathrm{HCl}$ 4M. Penambahan ini bertujuan untuk membuat suasana asam karena $\mathrm{Fe}(\mathrm{III})$ dalam suasana asam dapat membentuk kompleks dengan ion $\mathrm{SCN}^{-}$menjadi $\left[\mathrm{Fe}(\mathrm{SCN})_{6}\right]^{3-}$. Kandungan $\mathrm{Fe}(\mathrm{III})$ dalam air hujan di sekitar industri, pegunungan dan pemukiman dapat dilihat pada Tabel 3.

Tabel 3. Hasil Pengukuran Fe(III) dalam Sampel Air Hujan

\begin{tabular}{ccc}
\hline $\begin{array}{c}\text { Lokasi } \\
\text { Sampling }\end{array}$ & $\begin{array}{c}\text { Kandungan Fe(III) } \\
(\mathrm{mg} / \mathrm{L})\end{array}$ & $\begin{array}{c}\text { Fe(III) } \\
(\%)\end{array}$ \\
\hline Industri & 0,5198 & 85,70 \\
Pegunungan & 0,4994 & 69,11 \\
Pemukiman & 0,5672 & 88,58 \\
\hline
\end{tabular}

Berdasarkan hasil pengukuran, kandungan $\mathrm{Fe}(\mathrm{III})$ tertinggi dihasilkan pada lokasi hasil penampungan air hujan sekitar pemukiman. Kandungan $\mathrm{Fe}(\mathrm{III})$ tertinggi dalam air hujan selanjutnya yaitu pada industri sedangkan yang terkecil yaitu pada daerah pegunungan. Tingginya kandungan $\mathrm{Fe}$ (III) di berbagai lokasi hasil penampungan air hujan yang turun di sekitar industri, pegunungan dan pemukiman karena $\mathrm{Fe}$ (III) merupakan logam yang lebih stabil dibandingkan $\mathrm{Fe}(\mathrm{II})$ sehingga $\mathrm{Fe}(\mathrm{II})$ dalam air hujan akan teroksidasi menjadi Fe(III). Perbedaan kandungan $\mathrm{Fe}(\mathrm{III})$ pada air hujan disetiap kawasan dikarenakan adanya partikulat yang tidak bertahan lama di atmosfer sehingga turun kembali ke permukaan melalui air hujan. Partikulat ini yang menyebabkan tingginya kandungan $\mathrm{Fe}(\mathrm{III})$ dalam air hujan di berbagai kawasan penampungan air hujan.

\section{pH Air Hujan}

$\mathrm{pH}$ air hujan yang dihasilkan dari berbagai kawasan penampungan air hujan dapat dilihat pada Tabel 4.

Tabel 4. Hasil Pengukuran $\mathrm{pH}$ dalam air hujan

\begin{tabular}{cc}
\hline Lokasi Sampling & $\mathrm{pH}$ \\
\hline Industri & 5,67 \\
Pegunungan & 5,93 \\
Pemukiman & 5,92 \\
\hline
\end{tabular}

Tabel 4 dapat dilihat pada bahwa rata-rata hasil pengukuran yaitu diantara 5,67-5,93. Hasil tersebut menunjukkan bahwa $\mathrm{pH}$ air hujan dari tiga lokasi ini termasuk ke dalam air hujan alami. Karena pH air hujan alami yaitu sekitar 5,56. Namun terdapat perbedaan $\mathrm{pH}$ hasil pengukuran antar lokasi. Pada lokasi industri menunjukkan $\mathrm{pH}$ 
yang lebih asam diantara pegunungan dengan pemukiman. Hal ini disebabkan karena di industri mengeluarkan gas seperti karbondioksia $\left(\mathrm{CO}_{2}\right)$, sulfur dioksida $\left(\mathrm{SO}_{2}\right)$ dan nitrogen oksida $\left(\mathrm{NO}_{\mathrm{x}}\right)$ sehingga akan bereaksi dengan air hujan yang dapat menyebabkan air hujan menjadi sedikit asam. Sedangkan untuk $\mathrm{pH}$ air hujan sekitar pegunungan dan pemukiman menunjukan $\mathrm{pH}$ yang lebih tinggi dibandingkan dengan $\mathrm{pH}$ air hujan di sekitar industri hal ini disebabkan karena daerah pegunungan dan pemukiman tidak terlalu dipengaruhi oleh gas seperti karbondioksia $\left(\mathrm{CO}_{2}\right)$, sulfur dioksida $\left(\mathrm{SO}_{2}\right)$ dan nitrogen oksida $\left(\mathrm{NO}_{\mathrm{x}}\right)$.

\section{Pemindaian Fe(II)}

Pemindaian $\mathrm{Fe}(\mathrm{II})$ menggunakan senyawa $\mathrm{FeSO}_{4} .7 \mathrm{H}_{2} \mathrm{O}$ dimana senyawa tersebut digunakan sebagai sumber $\mathrm{Fe}(\mathrm{II})$ dan ligan yang digunakan yaitu fenantrolina sehingga menghasilkan senyawa kompleks $\left[\mathrm{Fe}(\mathrm{phen})_{3}\right]^{+2}$. Gambar 1 dan Gambar 2 merupakan hasil dari pemindaian $\mathrm{Fe}(\mathrm{II})$ pada panjang gelombang 400-800 $\mathrm{nm}$. Panjang gelombang 400-800 $\mathrm{nm}$ merupakan panjang gelombang sinar tampak (visible) untuk mengukur larutan berwarna.

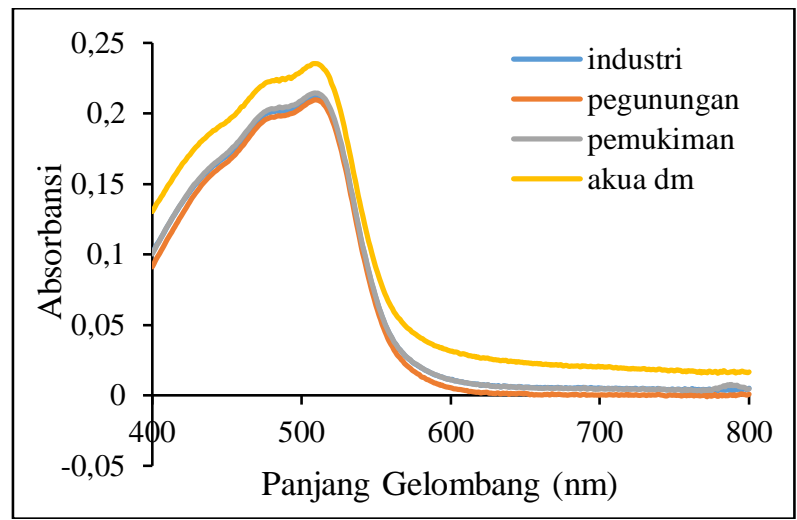

Gambar 1. Hasil Pemindaian Panjang Gelombang $\mathrm{Fe}(\mathrm{II})\left(\mathrm{FeSO}_{4} .7 \mathrm{H}_{2} \mathrm{O}\right.$ Pro Analisis)

Gambar 1 menunjukkan bahwa kandungan $\mathrm{Fe}(\mathrm{II})$ tertinggi dihasilkan dari pelarutan dengan aqua $\mathrm{dm}$ karena dalam aqua dm tidak adanya pengaruh dari oksidator maupun reduktor selain itu karena kandungan $\mathrm{Fe}$ (II) dalam $\mathrm{FeSO}_{4} .7 \mathrm{H}_{2} \mathrm{O}$ pro analisis terjamin kualitasnya sehingga sebagian besar tetap sebagai Fe(II). Kandungan $\mathrm{Fe}(\mathrm{II})$ dengan pelarutan air hujan lebih rendah dibandingkan dengan pelarutan menggunakan aqua $\mathrm{dm}$ hal ini terjadi karena adanya efek oksidasi dari air hujan sehingga sebagian $\mathrm{Fe}(\mathrm{II})$ teroksidasi menjadi $\mathrm{Fe}$ (III) karena $\mathrm{Fe}$ (II) keadaannya lebih tidak stabil dibandingkan $\mathrm{Fe}(\mathrm{III})$ dan mudah untuk teroksidasi menjadi $\mathrm{Fe}$ (III). Sehingga kandungan Fe(II) pada Gambar 1 lebih sedikit dibandingkan kandungan $\mathrm{Fe}$ (II) dalam Gambar 2 Untuk hasil pemindaian panjang gelombang $\mathrm{Fe}(\mathrm{II})$ dalam $\mathrm{FeSO}_{4} .7 \mathrm{H}_{2} \mathrm{O}$ teknis dapat dilihat pada Gambar 2.

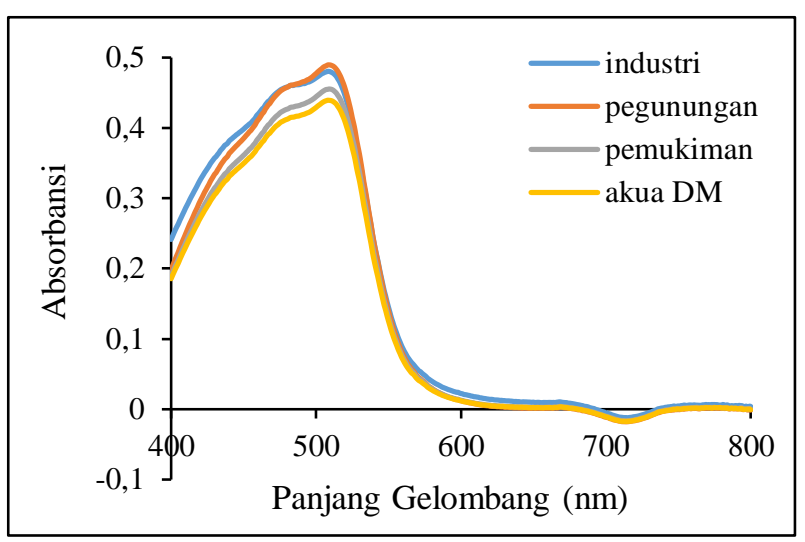

Gambar 2. Hasil Pemindaian panjang gelombang $\mathrm{Fe}(\mathrm{II})\left(\mathrm{FeSO}_{4} \cdot 7 \mathrm{H}_{2} \mathrm{O}\right.$ teknis $)$

Gambar 2 diperoleh pelarutan menggunakan air hujan menghasilkan kandungan $\mathrm{Fe}(\mathrm{II})$ lebih tinggi dibandingkan hasil pelarutan dengan menggunakan aqua Dm. Hal ini terjadi karena adanya pengaruh reduktor dalam air hujan dari $\mathrm{Fe}(\mathrm{III})$ menjadi $\mathrm{Fe}(\mathrm{II})$ dapat dilihat pada Gambar 2 yang menghasilkan kandungan $\mathrm{Fe}(\mathrm{II})$ yang meningkat dibandingkan Gambar 1. Kandungan Fe(II) yang dihasilkan pada Gambar 1 berbanding terbalik dengan kandungan $\mathrm{Fe}(\mathrm{II})$ pada Gambar 2. Hal ini terjadi karena senyawa $\mathrm{FeSO}_{4} .7 \mathrm{H}_{2} \mathrm{O}$ yang digunakan teknis sehingga tidak terjamin kestabilannya dan mudah teroksidasi menjadi Fe(III). Berdasarkan hasil pemindaian pada Gambar 1 dan Gambar 2 mengalami reaksi oksidasi maupun reduksi dalam air hujan. Air hujan selain mengandung besi total, besi(II) dan besi(III) mengandung juga hidrogen peroksida $\left(\mathrm{H}_{2} \mathrm{O}_{2}\right)$. Hidrogen peroksida bertindak sebagai oksidator [9] maupun reduktor yang mempengaruhi potensi redoks dalam air hujan [8].

\section{SIMPULAN}

Hasil penelitian ini dapat ditarik kesimpulan bahwa kandungan $\mathrm{Fe}$ total, $\mathrm{Fe}$ (II) dan Fe(III) dalam air hujan yang turun di kawasan industri, pegunungan dan pemukiman yaitu $\mathrm{Fe}$ total 0,5655 ; 1,6854; dan 2,4232 mg/L, Fe(II) 0,0867; 0,2232; $0,0731 \mathrm{mg} / \mathrm{L}$ dan $\mathrm{Fe}(\mathrm{III})$ 0,5198; 0,4994; dan $0,5672 \mathrm{mg} / \mathrm{L}$ serta perbandingannya dalam air hujan bahwa persentase kandungan Fe(III) lebih besar dibandingkan persentase kandungan $\mathrm{Fe}(\mathrm{II})$. Perbandingan geseran panjang gelombang maksimum sinar tampak larutan $\mathrm{FeSO}_{4} .7 \mathrm{H}_{2} \mathrm{O}$ teknis dan pro analisis dengan pengompleks 
fenantrolin diperoleh bahwa air hujan memiliki daya reduksi terhadap ion $\mathrm{Fe}^{3+}$.

\section{UCAPAN TERIMA KASIH}

Penulis mengucapkan terima kasih kepada Bapak Yusuf Rohmatulloh, S.Si. atas bantuan teknis dan diskusi analisis spektroskopi serapan atom untuk besi.

\section{REFERENSI}

[1] Tukidi, Karakter Curah Hujan di Indonesia. Unnes, 2010.

[2] B.C. Mathelumual, "Potensi Terjadinya Hujan Asam di Kota Bandung", Lingkungan dan Bencana Geologi, vol. 1, pp. 59-70, 2009.

[3] K. Takeda dan S. Sosrodarsono, Hidrologi untuk Pengairan. Jakarta: PT Pradnya Paramita, 2003.

[4] N. Bouchard, K. Harmon, H. Markham, dan S. Vandefifer, "Effect of Various Types of Water on the Growth of Radishes (Raphanus sativus)," 2007.
[5] Hefni Effendi, Telaah Kualitas Air. Yogyakarta: Kanisius, 2003.

[6] J.D. willey dan R.J. Kieber, "The Role of Fossil Combustion on The Stability of Dissolved Iron in Rainwater," Atmospheric Environment, vol. 107, pp. 187-193, 2015.

[7] G.R. Rout dan S. Sahoo, "Role of Iron in Plant Growth and Metabolism," Agricultural Science, vol. 3, pp. 1-24, 2015.

[8] J.D. Willey, K.M. Mullaugh, R.J. Kieber, G.B.A. Jr, dan R.N. Mead, "Controls on the Redox Potential of Rainwater," Environmental Science and Technology, vol. 45, pp. 13103-13111, 2012.

[9] R.J Kieber, B. Peake, J.D Willey, dan B. Jacob, "Iron Specation and Hydrogen Peroxide Concentrations in New Zealand Rainwater," Atmospheric Invorenment, 2001.

[10] A.I.A.B. Sreea, A.A.A.A. Yassen, dan A.A. El Kazzaz, "Effect of Iron(II) Sulfate and Potassium Humate on Growth and Chemical Composition of Coriandum sativum L," Agricultural Research, vol. 04, pp. 136-145, 2017. 